\title{
Polycythemia Vera Blood Burst-forming Units-Erythroid Are Hypersensitive to Interleukin-3
}

\author{
C. H. Dai," S. B. Krantz," R. T. Means, Jr., ${ }^{\star}$ S. T. Horn," and H. S. Gilbert* \\ *Departments of Medicine, Department of Veterans Affairs Medical Center and Vanderbilt School of Medicine, \\ Nashville, Tennessee 37232; and ${ }^{\ddagger}$ Albert Einstein College of Medicine, Bronx, New York 10461
}

\begin{abstract}
Because polycythemia vera (PV) is a clonal hematopoietic stem cell disease with a trilineage hyperplasia, and interleukin-3 (IL-3) stimulates trilineage hematopoiesis, we have studied the response of highly purified PV blood burst-forming unitserythroid (BFU-E) to recombinant human IL-3 (rIL-3). Whereas the growth of normal blood BFU-E in vitro rapidly declined by 40 and $60 \%$ after 24 and $48 \mathrm{~h}$ of incubation without $50 \mathrm{U} / \mathrm{ml}$ of rIL-3, the growth of PV BFU-E declined by only 10 and $30 \%$ under the same conditions, demonstrating a reduced dependence on rIL-3. A reduced dependence of PV BFU-E on recombinant human erythropoietin (rEP) was also present. Dose-response experiments showed a 117-fold increase in PV BFU-E sensitivity to rIL-3, and a 6.5-fold increase in sensitivity to rEP, compared to normal BFU-E, whereas blood BFU-E from patients with secondary polycythemia responded like normal BFU-E. Endogenous erythroid colony (EEC) formation, which is independent of the addition of $\mathrm{rEP}$, was reduced by $\mathbf{5 0 \%}$ after erythroid colony-forming cells were generated from PV BFU-E in vitro without rIL-3 for 3 d, whereas rEP-stimulated erythroid colonies were unaffected. These studies demonstrate a striking hypersensitivity of PV blood BFU-E to rIL-3, which may be the major factor in the pathogenesis of increased erythropoiesis without increased EP concentrations. (J. Clin. Invest. 1991. 87:391-396.) Key words: myeloproliferative disease • cytokines • erythroid progenitors • erythropoietin
\end{abstract}

\section{Introduction}

Polycythemia vera (PV) ${ }^{1}$ is a clonal disease of the hematopoietic stem cell which is characterized by a trilineage hyperplasia of the marrow, leukocytosis, thrombocytosis, and erythrocyto-

Address reprint requests to Dr. Sanford B. Krantz, Dept. of Medicine, Vanderbilt Medical Center North C-3101, Nashville, TN 37232-2287.

Received for publication 24 January 1990 and in revised form 12 September 1990.

1. Abbreviations used in this paper: $\mathrm{AB}^{-}$, antibody-negative cells; $\mathrm{BFU}$ E, burst-forming units-erythroid; D-BSA, deionized BSA; D-PBS, Dulbecco's PBS; ECFC, erythroid colony-forming cells; EEC, endogenous erythroid colonies; EP, erythropoietin; FH, Ficoll-Hypaque; IL-3, interleukin-3; IMDM, Iscove's modified Dulbecco's medium; IMDM-P, Iscove's modified Dulbecco's medium used for panning; 2-ME, 2-mercaptoethanol; $\alpha \mathrm{MEM}$, alpha minimum essential medium; PV, polycythemia vera; rEP, recombinant human erythropoietin; rIL-3, recombinant human interleukin-3.

J. Clin. Invest.

(C) The American Society for Clinical Investigation, Inc.

$0021-9738 / 91 / 02 / 0391 / 06 \$ 2.00$

Volume 87, February 1991, 391-396 sis (1). However, the control of red cell production has been principally studied because polycythemia is the primary clinical manifestation. It has been shown that the increased erythropoiesis is not the result of increased erythropoietin (EP) production, but reflects the proliferation of the abnormal clone in the absence of increased EP $(1,2)$. When marrow cells from PV patients were cultured, endogenous erythroid colonies (EEC) formed without the addition of EP, and were $9-37 \%$ of the erythroid colonies seen with EP (3). Zanjani et al. (4), Golde et al. (5), and Casadevall et al. (6) provided evidence that erythropoiesis in $\mathrm{PV}$ is hypersensitive to EP, whereas other investigators suggested that it might be independent of EP $(7,8)$. Recently PV CFU-E have been shown to have a normal number of low-affinity EP receptors, but to lack high-affinity EP receptors, which indicates that any enhanced EP sensitivity is unlikely to be due to enhanced EP binding to these cells (9).

In the last year, we have developed a method for enriching normal human blood burst-forming units-erythroid (BFU-E) to $57 \%$ purity, with a range of $45-79 \%$, and have characterized the growth requirements for these cells (10). As with human marrow cells $(11,12)$, interleukin-3 (IL-3) is needed early in the course of BFU-E development in vitro while EP is needed later (10). Because this method allows us to obtain highly purified BFU-E, and because IL-3 is a cytokine that acts upon early hematopoietic cells to provide trilineage growth enhancement (13), which is seen in PV, we have purified PV BFU-E and have studied the response of these cells to IL-3 and EP. These investigations show that PV blood BFU-E are much more hypersensitive to IL-3 than to EP and this may account for the increased growth and differentiation of PV erythroid cells in the absence of enhanced EP concentrations.

\section{Methods}

Blood samples. $400 \mathrm{ml}$ of peripheral blood was obtained from normal adults and from patients meeting established criteria for $\mathrm{PV}$ and secondary polycythemia (14), who signed consent forms approved by the Vanderbilt Committee for the Protection of Human Subjects and the Department of Veterans Affairs Research and Development Committee. Four of the PV patients were treated only with phlebotomy, whereas one received hydroxyurea, $500 \mathrm{mg}$ every other day, in addition to phlebotomy. Two of the patients with secondary polycythemia had severe chronic obstructive pulmonary disease; two had renal disease (cyst and stones) with increased serum erythropoietin levels; and one had unilateral hydronephrosis associated with previous surgery for carcinoma of the prostate. The blood was collected in sodium heparin (Upjohn Co., Kalamazoo, MI) at a final concentration of $20 \mathrm{U} / \mathrm{ml}$.

$B F U-E$ purification. This method has been previously described (10). In brief, the mononuclear cells were separated over Ficoll-Hypaque $\left(\mathrm{FH} ; 1.077 \mathrm{~g} / \mathrm{cm}^{3}\right.$, Pharmacia Fine Chemicals, Piscataway, NJ; Winthrop-Breton Laboratories, New York, NY) at $400 \mathrm{~g}$ for $25 \mathrm{~min}$ at $24^{\circ} \mathrm{C}$. For PV samples, either buffy coat cells were suspended in an equal volume of alpha minimum essential medium ( $\alpha$ MEM) (Sigma Chemical Co., St. Louis, MO), or the blood was diluted with one-half 
volume of Dulbecco's PBS (Sigma Chemical Co.) containing $13.6 \mathrm{mM}$ sodium citrate (D-PBS) (Sigma Chemical Co.), before separation by FH (9). The interface mononuclear FH cells were collected, washed twice with D-PBS at $600 \mathrm{~g}, 24^{\circ} \mathrm{C}$, for $15 \mathrm{~min}$ and were resuspended in $20 \mathrm{ml}$ of D-PBS. The cell suspension was overlaid on $30 \mathrm{ml}$ of $10 \% \mathrm{BSA}$ (Armour Pharmaceutical Co., Kankakee, IL) in D-PBS and centrifuged at $180 \mathrm{~g}, 24^{\circ} \mathrm{C}$, for $10 \mathrm{~min}$ to remove platelets. This procedure was repeated and the cells were washed thrice with $\alpha$ MEM before suspending them in $\alpha$ MEM at $1 \times 10^{7} / \mathrm{ml}$.

The cells then were incubated with one-half volume of neuraminidase-treated and one-half volume of IgG-coated sheep erythrocytes for $10 \mathrm{~min}$ in a $37^{\circ} \mathrm{C}$ water bath (10). After centrifugation at $130 \mathrm{~g}, 24^{\circ} \mathrm{C}$, for $10 \mathrm{~min}$, the cells were placed in ice for $60 \mathrm{~min}$ and were then dispersed and separated over $\mathrm{FH}$ at $400 \mathrm{~g}, 24^{\circ} \mathrm{C}$, for $15 \mathrm{~min}$. The interface mononuclear cells were washed thrice with $\alpha$ MEM and resuspended at $2 \times 10^{7} / \mathrm{ml}$ in Iscove's modified Dulbecco's medium (IMDM) (Sigma Chemical Co.), containing $36 \mathrm{mM} \mathrm{NaCl}$ instead of $\mathrm{NaHCO}_{3}$, with the $\mathrm{pH}$ adjusted to $\mathrm{pH} 7.3$ using $\mathrm{NaOH}$. This IMDM was used for "panning" (IMDM-P) and had 1.0\% deionized (15) BSA (D-BSA) with $2 \times 10^{7}$ cells per $\mathrm{ml}$.

The cells then were mixed with an equal volume of CD34/antiMy10 murine hybridoma tissue culture supernatant $(16,17)$ at $3^{\circ} \mathrm{C}$ and were incubated for $30 \mathrm{~min}$ at $3^{\circ} \mathrm{C}$ using an end-over-end rotator. The cells were washed thrice with IMDM-P containing $0.25 \%$ D-BSA (washing medium) using the cell protection washing procedure previously described (10). The cells were resuspended at $3 \times 10^{7} / \mathrm{ml}$ in IMDM-P, containing $1 \%$ D-BSA, for incubation with a threefold excess of immunomagnetic microspheres (Dynabeads M-450 coated with goat anti-mouse IgG; Dynal Inc., Great Neck, NY) at $3^{\circ} \mathrm{C}$ over 50 min using an end-over-end rotator. The cell-bound microspheres were attached to the tube wall by a magnet (model MPC-1; Dynal Inc.) and the free cells were removed by washing the tube four times with $3 \mathrm{ml}$ of washing medium plus two times with IMDM-P at $3^{\circ} \mathrm{C}$. After removal of the magnet, the cells that bound microspheres were gently pipetted for $30 \mathrm{~s}$ with $1.5 \mathrm{ml}$ of IMDM-P containing $130 \mathrm{U} / \mathrm{ml}$ of chymopapain (Chymodiactin; Boots Company Inc., Lincolnshire, IL) and $0.02 \mathrm{M}$ EDTA (Fischer Scientific Co., Pittsburgh, PA), at $37^{\circ} \mathrm{C}$, and were incubated for another $30 \mathrm{~s}$ at $37^{\circ} \mathrm{C}$. The magnet was applied and the cells released from the microspheres were collected and mixed with $1.5 \mathrm{ml}$ heat-inactivated FCS (fraction 1). This procedure was repeated another three times (fractions 2-4). The cells from fractions 2-4 were pooled as

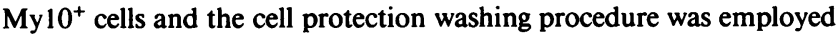
before resuspending the cells in IMDM containing $0.1 \%$ D-BSA.

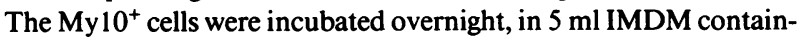
ing $20 \%$ heat-inactivated $\mathrm{FCS}, 10 \%$ pooled human heat-inactivated $A B$ serum, $1 \%$ D-BSA, $50 \mathrm{U} / \mathrm{ml}$ recombinant human IL-3 (rIL-3) $\left(10^{8}\right.$ $\mathrm{U} / \mathrm{mg}$ protein; AMGen Biologicals, Thousand Oaks, CA), $2 \mathrm{U} / \mathrm{ml}$ recombinant human EP (rEP), (128,000 U/mg; Ortho Pharmaceutical Corp., Raritan, NJ), $10 \mu \mathrm{g} / \mathrm{ml}$ porcine insulin, (26.3 USP U/mg; Calbiochem-Behring Diagnostics, La Jolla, CA), $5 \times 10^{-5}$ M 2-mercaptoethanol (2-ME), (Eastman-Kodak Co., Rochester, NY), penicillin at $500 \mathrm{U} / \mathrm{ml}$ and streptomycin at $40 \mu \mathrm{g} / \mathrm{ml}$, in $25 \mathrm{~cm}^{2}$ tissue culture polystyrene flasks (Becton-Dickinson, Oxnard, $\mathrm{CA}$ ) at $37^{\circ} \mathrm{C}$, in a $5 \% \mathrm{CO}_{2} /$ 95\% atmosphere incubator.

The nonadherent day 1 cells were collected and suspended in IMDM-P containing $1 \%$ D-BSA. Nine murine monoclonal antibodies to CD15/anti-My1, CD33/anti-My9, CD45R/anti-My11, CD16/antiMy23, CD56/anti-My31 (17-22), CD7/anti-Leu9, CD20/anti-Leu16 (Becton-Dickinson), CD2/anti-OKT*1, and CD11b/anti-OKM*1 (Ortho Pharmaceutical Corp.) were added as previously described (10) and the cell suspension was incubated for $30 \mathrm{~min}$ at $3^{\circ} \mathrm{C}$ with end-overend rotation. The cell protection washing procedure was used and the cells were resuspended in IMDM-P containing $1 \%$ D-BSA before being mixed with two series of immunomagnetic microspheres: one coated with affinity purified goat anti-mouse IgG (Dynal, Inc.) and another (Dynabeads M-450, Tosylactivated; Dynal, Inc.) coated with affinity purified goat anti-mouse IgM ( $\mu$-chain specific; Cappel Laboratories, West Chester, PA). The cells then were incubated for $60 \mathrm{~min}$, at $3^{\circ} \mathrm{C}$, with end-over-end rotation and those which did not bind microspheres were collected by magnetic separation. These cells were overlaid on FH and centrifuged at $600 \mathrm{~g}$ for $5 \mathrm{~min}$ at $24^{\circ} \mathrm{C}$ to remove dead cells. The interface mononuclear cells were collected and the cell protection washing procedure was employed before resuspending the cells in IMDM containing $0.3 \%$ D-BSA. The cell concentration and the viability of the cells were measured by hemocytometer and dye exclusion using $0.2 \%$ Trypan blue dye (23). The cells were kept at $3^{\circ} \mathrm{C}$ until use (day $1 \mathrm{AB}^{-} \mathrm{FH}$ cells).

Erythroid colony-forming cell (ECFC) purification. ECFC were generated in vitro from partially purified BFU-E and are defined as cells that give rise to single colonies of 2-49 hemoglobinized cells after $7 \mathrm{~d}$ of culture with EP $(24,25)$. The blood BFU-E were purified by the method of Sawada et al. (24) as modified by Means et al. (9). Briefly, heparinized peripheral blood was centrifuged over $\mathrm{FH}$, treated with citrated PBS/BSA, and depleted of T-lymphocytes as described above. The remaining mononuclear cells underwent overnight adherence in plastic flasks in the presence of $20 \%$ heat-inactivated FCS and $0.4 \%$ giant cell tumor conditioned medium (Gibco Laboratories, Grand Island, NY) under conditions already described.

The following morning (day 1), the nonadherent cells were collected by gentle washing with $37^{\circ} \alpha \mathrm{MEM}$. These cells then were suspended at a concentration of $70 \times 10^{6} / \mathrm{ml}$ in $25 \mu \mathrm{lCD} 1 \mathrm{lb} /$ anti-OKM*1 $(20 \mu \mathrm{g} / \mathrm{ml}), 25 \mu \mathrm{l} \mathrm{CD} 2 /$ anti-OKT ${ }^{*} 11(10 \mu \mathrm{g} / \mathrm{ml}$; Ortho), $50 \mu \mathrm{l} \mathrm{CD} 45 \mathrm{R} /$

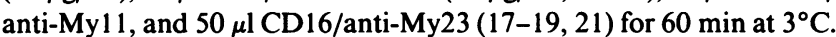
The cells were washed thrice and incubated in $100-\mathrm{mm}$ plastic tissue culture dishes, which had previously been coated with affinity purified goat anti-mouse IgG (Boehringer Mannheim Biochemicals, Indianapolis, IN), for $90 \mathrm{~min}, 3^{\circ} \mathrm{C}$, to remove residual granulocytes, monocytes, granulocyte-macrophage progenitors, T- and B-lymphocytes, and natural killer cells.

The remaining day 1 cells were collected in IMDM and cultured at $3.0 \times 10^{5} / \mathrm{ml}$ in $0.9 \%$ methylcellulose (Fisher Scientific Co., Pittsburgh, PA) with $30 \%$ heat-inactivated FCS, $1 \%$ BSA, $10^{-4} \mathrm{M} 2-\mathrm{ME}, 500 \mathrm{U} / \mathrm{ml}$ penicillin, $40 \mu \mathrm{g} / \mathrm{ml}$ streptomycin, $50 \mathrm{U} / \mathrm{ml} \mathrm{rIL}-3,10 \mathrm{U} / \mathrm{ml}$ recombinant human insulin ( $26 \mathrm{U} / \mathrm{mg}$; Eli Lilly \& Co., Indianapolis, IN), and rEP $2 \mathrm{U} / \mathrm{ml}$ for $4 \mathrm{~d}$ at $37^{\circ}$ in a high humidity $5 \% \mathrm{CO}_{2}$ incubator.

On day 5 , the cells were collected in $\alpha$ MEM and separated over $10 \%$ BSA as described above. Adherent cells were removed by incubation in plastic flasks for $1 \mathrm{~h}$ at $37^{\circ} \mathrm{C}$ with $20 \%$ heat-inactivated FCS. The nonadherent cells were collected and incubated at $37^{\circ} \mathrm{C}, 1 \mathrm{~h}$, in IMDM with $0.1 \%$ BSA to remove any surface-bound growth factors (26). The cells then were layered onto $2 \mathrm{ml} \mathrm{FH}$ and centrifuged at $600 \mathrm{~g}, 3^{\circ} \mathrm{C}$, for $5 \mathrm{~min}$. The interface cells were washed and collected in IMDM.

These cells were cultured for $3 \mathrm{~d}$ at $37^{\circ} \mathrm{C}$ in a $5 \% \mathrm{CO}_{2}$ incubator at a concentration of $3.0 \times 10^{5} / \mathrm{ml}$ in IMDM with $30 \%$ heat-inactivated FCS, $1 \% \mathrm{BSA}, 10^{-4} \mathrm{M} 2-\mathrm{ME}, 500 \mathrm{U} / \mathrm{ml}$ penicillin, $40 \mu \mathrm{g} / \mathrm{ml}$ streptomycin, $10 \mathrm{U} / \mathrm{ml}$ recombinant human insulin, and rEP $2 \mathrm{U} / \mathrm{ml}$. rIL-3, 50 $\mathrm{U} / \mathrm{ml}$, was added to half the culture wells.

On day 8 , the cells were collected, separated over $10 \%$ BSA, and incubated in IMDM with $0.1 \%$ BSA as on day 5. Cells which had been exposed to rIL-3 for all $7 \mathrm{~d}$ were handled separately from those which had been exposed to rIL-3 days 1-5 only and both were assayed for ECFC.

$B F U-E$ assay. The purified day $1 \mathrm{AB}^{-} \mathrm{FH}$ cells were plated at 100 200 cells $/ \mathrm{ml}$ in a $0.5 \mathrm{ml}$ mixture containing $20 \%$ heat-inactivated FCS, $10 \%$ heat-inactivated pooled human AB serum, $1 \%$ D-BSA, $5 \times 10^{-5} \mathrm{M}$ 2-ME, $1.5 \mathrm{mM}$ aminocaproic acid (Elkins-Sinn, Inc., Cherry Hill, NJ), penicillin-streptomycin, $10 \mu \mathrm{g} / \mathrm{ml}$ insulin, $2 \mathrm{U} / \mathrm{ml} \mathrm{rEP}, 50 \mathrm{U} / \mathrm{ml} \mathrm{rIL-3,}$ $2 \mathrm{mg} / \mathrm{ml}$ human fibrinogen, (grade L, coagulability $90 \%$ of total protein content; KabiVitrum, Stockholm, Sweden), $0.2 \mathrm{U} / \mathrm{ml}$ thrombin (Parke-Davis, Morris Plains, NJ) and IMDM in 24-well flat-bottomed tissue culture plates (Linbro; Flow Laboratories, Inc., McLean, VA). In some experiments, which concerned the effect of delayed addition of rEP and rIL-3 on BFU-E development, the day $1 \mathrm{AB}^{-} \mathrm{FH}$ cells were plated into $0.5-\mathrm{ml}$ plasma clots without rEP or rIL-3 and then $0.2 \mathrm{ml}$ IMDM containing $20 \%$ FCS and $1.4 \mathrm{U}$ rEP, or $35 \mathrm{U}$ rIL-3, was overlaid on the clots on the indicated days. 

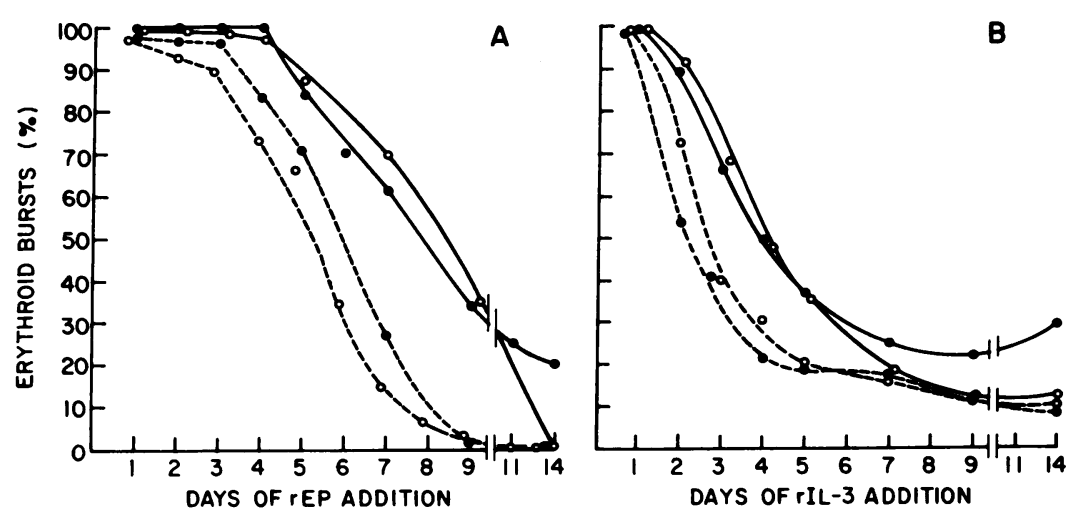

Figure 1. The effect of delayed addition of $\operatorname{rEP}(A)$ or rIL-3 $(B)$ on blood BFU-E development from two normal (- - ) and two PV (-) subjects. The BFU$E$ were plated in $0.5-\mathrm{ml}$ plasma clots at concentrations of $150-200 \mathrm{cells} / \mathrm{ml}$ with $50 \mathrm{U} / \mathrm{ml}$ of rIL-3 $(A)$ or 2 $\mathrm{U} / \mathrm{ml}$ of $\mathrm{rEP}(B)$. At the indicated times, $0.2 \mathrm{ml}$ of IMDM, containing $20 \%$ FCS and $1.4 \mathrm{U} \operatorname{rEP}(A)$ or 35 U rIL-3 $(B)$ was overlaid on the clots. The cells were incubated for $15 \mathrm{~d}$ and then fixed and stained with benzidine-hematoxylin. The number of erythroid bursts observed in clots plated on day 1 with both rEP and rIL-3 was taken as $100 \%$ expression. Each value is the mean of triplicates. The BFU-E purity was $62 \pm 4 \%, 47 \pm 9 \%$ (normal); $61 \pm 9 \%$ and $89 \pm 5 \%$ (PV) (mean $\pm \mathrm{SD}$ ). One $\mathrm{PV}$ patient $(0)$ received hydroxyurea $500 \mathrm{mg}$ every other day in addition to phlebotomy while the other was treated by phlebotomy alone.
The cultures were incubated in a $5 \% \mathrm{CO}_{2} / 95 \%$ atmosphere, at $37^{\circ} \mathrm{C}$, in a fully humidified incubator for $15 \mathrm{~d}$. At the end of the incubation, the clots were removed and transferred to glass slides, fixed in 5\% glutaraldehyde and then stained with benzidine-hematoxylin (15). Enumeration of BFU-E was performed as described by Clark and Housman (27). Examination of purified PV day $1 \mathrm{AB}^{-} \mathrm{FH}$ cells for ECFC in six cultures has shown that $3.8 \pm 1.3 \%$ of the erythroid progenitors were ECFC.

ECFC assay. Day 8 cells were assayed for ECFC by the plasma clot method of McLeod et al. (15). Cells were cultured at $10^{3} / \mathrm{ml}$ in $0.2-\mathrm{ml}$ aliquots, using 48 -well tissue culture plates, for $7 \mathrm{~d}$ at $37^{\circ} \mathrm{C}$ in a $5 \% \mathrm{CO}_{2}$ high-humidity incubator. The plating mixture contained $15 \%$ heat-inactivated FCS, $15 \%$ heat-inactivated pooled AB serum, 1\% D-BSA, penicillin and streptomycin, $1 \mathrm{U} / \mathrm{ml} \mathrm{rEP}, 2 \mathrm{mg} / \mathrm{ml}$ fibrinogen, $0.2 \mathrm{U} /$ $\mathrm{ml}$ thrombin, $0.2 \mathrm{M}$ aminocaproic acid, and IMDM. Clots were fixed and stained as described above. EEC formation is defined as the growth of erythroid colonies without the addition of $\operatorname{rEP}(3-5,28)$. Statistical comparison was by $t$ test.

\section{Results}

Dependency of normal and PV blood BFU-E on rEP and rIL-3. Purified BFU-E were plated into plasma clots with the omission of either rEP or rIL-3, and the omitted factor was added at 24-h intervals. In the presence of $50 \mathrm{U} / \mathrm{ml} \mathrm{rIL-3,90 \%} \mathrm{of} \mathrm{normal}$ BFU-E formed erythroid bursts after an absence of rEP for 48 $\mathrm{h}$, and $50 \%$ after an absence of rEP for as long as $120 \mathrm{~h}$ (Fig. 1 A). PV BFU-E could be deprived of rEP for two additional days and still retain an equivalent capacity to form erythroid bursts
(Fig. $1 \mathrm{~A}$ ). Whereas the blood BFU-E from one PV patient did not show EEC formation in this experiment, a replicate blood from the same patient did have EEC (Fig. 2).

When normal BFU-E were plated with $2 \mathrm{U} / \mathrm{ml} \mathrm{rEP}$ and deprived of rIL-3 for 24 and 48 h erythroid burst formation was markedly reduced to 63 and $40 \%$ of BFU-E that had rIL-3 present the full time (Fig. 1 B). However, $90 \%$ of PV BFU-E continued to form erythroid bursts when deprived of rIL-3 for $24 \mathrm{~h}$ and $70 \%$ survived normally when deprived of rIL-3 for 48 $\mathrm{h}$ (Fig. $1 \mathrm{~B}$ ). PV BFU-E appeared less dependent on large concentrations of IL-3 and EP than normal BFU-E.

Sensitivity of normal and $P V$ blood BFU-E to $\mathrm{rEP}$ and $r I L$ 3. Fig. $2 A$ shows the dose-response relationship for normal and PV BFU-E which were incubated with a wide variety of rIL-3 concentrations and $2 \mathrm{U} / \mathrm{ml}$ of $\mathrm{rEP}$. An enhanced number of $\mathrm{PV}$ bursts occurred with increasing concentrations of rIL-3 when compared to normal burst formation. The rIL-3 concentration necessary for $50 \%$ expression of PV erythroid bursts was $0.004 \pm 0.001 \mathrm{U} / \mathrm{ml}$ compared to $0.467 \pm 0.162 \mathrm{U} / \mathrm{ml}$ for normal erythroid burst development $(P<0.005)$ demonstrating a 117 fold increase in the sensitivity of PV BFU-E to rIL-3. Almost twice as many erythroid bursts developed in the absence of rIL-3 from PV BFU-E, compared to normal BFU-E $(P<0.01)$, but a similar plateau occurred for the response of both classes of cells at $25 \mathrm{U} / \mathrm{ml}$. The increased number of PV erythroid bursts, compared to normal erythroid bursts, at all concentrations of rIL-3 from 0.001 to $1.0 \mathrm{U} / \mathrm{ml}$, was significant at each level with $P$ values from 0.018 to 0.00001 . The erythroid bursts
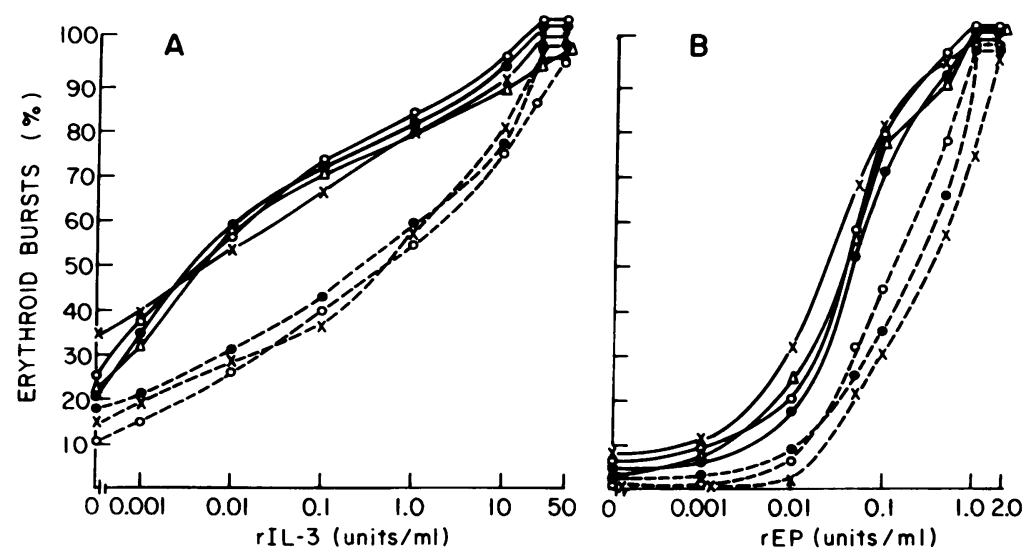

Figure 2. Comparison of rIL-3 $(A)$ and rEP $(B)$ doseresponse curves in $0.5-\mathrm{ml}$ plasma clot cultures of blood BFU-E from three normal (- - ) and four PV (-) subjects. The BFU-E were plated at $100-150$ cells $/ \mathrm{ml}$ with $\mathrm{rEP} 2 \mathrm{U} / \mathrm{ml}(A)$ or $\mathrm{rIL}-350 \mathrm{U} / \mathrm{ml}(B)$. Each point is the mean value of triplicates and is expressed as a percentage of the value obtained with the highest concentration of rIL-3 or rEP. The purity of the BFU-E was $42 \pm 8 \%, 51 \pm 3 \%, 40 \pm 11 \%$ (normal); $76 \pm 11 \%, 81 \pm 6 \%$, and $59 \pm 5 \%(P V)($ mean $\pm S D)$. One PV patient (0) received hydroxyurea $500 \mathrm{mg}$ every other day in addition to phlebotomy while the others were treated by phlebotomy alone. 
in PV were slightly larger than normal erythroid bursts, but no further difference in BFU-E size was present with increasing concentrations of rIL-3. A similar hypersensitivity of PV BFUE to rIL-3 was observed in the presence of only $0.1 \mathrm{U} / \mathrm{ml} \mathrm{rEP}$ and in this case the size of the erythroid bursts increased with increasing concentration of rIL-3 (data not shown).

The sensitivity of normal and PV BFU-E to increasing con-

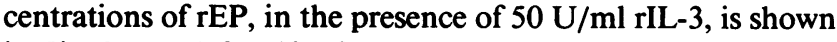
in Fig. $2 \boldsymbol{B}$. A left shift of the dose-response curve for rEP was also present with PV BFU-E, but it was far less than that seen with rIL-3. The rEP concentration necessary for $50 \%$ expression of erythroid bursts was $0.036 \pm 0.015 \mathrm{U} / \mathrm{ml}$ in PV compared to $0.233 \pm 0.111 \mathrm{U} / \mathrm{ml}$ with normal BFU-E $(P<0.05)$, a 6.5-fold increase in sensitivity. Without the addition of rEP $6 \pm 1 \%$ PV erythroid bursts were evident after $15 \mathrm{~d}$ of culture compared to $0.7 \pm 1 \%$ normal bursts $(P<0.01)$, but both groups of cells reached a plateau response at $1 \mathrm{U} / \mathrm{ml} \mathrm{rEP}$. Both the PV and the normal erythroid bursts were larger with increasing concentrations of rEP up to $0.5 \mathrm{U} / \mathrm{ml}$. A similar dose response relationship of normal and PV BFU-E, size of erythroid bursts, and tendency for increased burst size with increased rEP was seen with increasing concentrations of rEP in the presence of $0.5 \mathrm{U} / \mathrm{ml}$ of rIL-3 (data not shown).

Sensitivity of secondary polycythemia blood BFU-E to rEP and $r I L-3$. BFU-E from five patients with secondary polycythemia were cultured in plasma clots with increasing concentrations of rIL-3 (Fig. $3 A$ ) or rEP (Fig. $3 B$ ). The rIL-3 concentration $(0.54 \pm 0.38 \mathrm{U} / \mathrm{ml})$ and the $\mathrm{rEP}$ concentration $(0.15 \pm 0.07$ $\mathrm{U} / \mathrm{ml}$ ) necessary for $50 \%$ expression of erythroid burst development were not significantly different $(P>0.1)$ from those necessary for a similar development of normal erythroid bursts. However, these concentrations were significantly different from those necessary for $50 \%$ erythroid burst development by PV cells (rEP, $P<0.05$; rIL-3, $P<0.05$ ).

Relation of $r I L-3$ to EEC formation by PV ECFC. EEC formation was evaluated for ECFC generated for $7 \mathrm{~d}$ with rIL3 , and ECFC cultured for $4 \mathrm{~d}$ with rIL-3 and then $3 \mathrm{~d}$ without this cytokine. ECFC from three different patients with PV were studied, plus a repeat from one patient, and all showed EEC formation (Fig. 4). However, the cells that had been deprived of rIL-3 from day 5 to day 8 had a 50\% reduction in EEC growth. The reduction in EEC growth was localized to the EEC and was not related to a generalized cellular toxicity because the removal of rIL-3 had no effect on the growth of cells incubated with rEP (Fig. 4). The purity of ECFC $(51.7 \pm 21.5 \%$ from cells exposed to rIL-3 days $1-8$, and $52.5 \pm 23.7 \%$ from cells exposed to rIL-3 days 1-5) was unchanged. Normal ECFC were not studied because their EEC growth is usually $<0.5 \%(9,24)$.

\section{Discussion}

Studies on the control of proliferation and differentiation of PV cells generally have used highly impure blood or marrow cells and have focused on the response to EP. However, it has recently become possible to purify early erythroid progenitor cells without the need for specialized equipment using immunomagnetic microspheres and monoclonal antibodies. In addition, the genes for a variety of hematopoietic growth factors, which act on hematopoietic progenitor cells at earlier stages of development, have been cloned and expressed, and these cytokines are now available to study their role in pathologic processes. Because PV manifests a trilineage hyperplasia, and IL-3 enhances trilineage hematopoiesis, we have studied the response of highly purified PV BFU-E to rIL-3.

The studies reported here show that PV blood BFU-E can be enriched to $73 \pm 13 \%$ with a range of $59-89 \%$. The method is virtually the same as that used for the purification of normal human BFU-E except that the blood was either diluted with an equal volume of $\alpha \mathrm{MEM}$ or the buffy coat was removed and used for FH sedimentation to reduce the viscosity due to an increased concentration of red cells.

Whereas normal human erythroid burst formation was markedly reduced in number when the usual large concentration of rIL-3 was not added in the first 24-48 h of incubation, PV BFU-E had virtually complete survival when deprived of rIL-3 for $24 \mathrm{~h}$ and a comparatively modest decline after $48 \mathrm{~h}$ of deprivation. Because we thought that one possible reason for this might be a hypersensitivity to extremely low concentrations of IL-3 produced by some of the cells, or present in the medium, we performed rIL-3 and rEP dose-response curves for normal and PV BFU-E. A 6.5-fold increase in sensitivity of PV BFU-E to rEP, compared to normal BFU-E, was demonstrated with highly purified BFU-E. However, a 117-fold increase in sensitivity of purified PV BFU-E to rIL-3 was even more striking. It is possible that this might be due to the increased erythropoiesis that is evident in PV and for that reason similar experiments were performed with BFU-E from patients with secondary polycythemia. However, these BFU-E behaved in vitro like normal BFU-E.

Some investigators have reported an enhanced sensitivity of PV BFU-E to very low concentrations of Ep, but a normal sensitivity as the concentration of Ep is increased $(29,30)$. How-
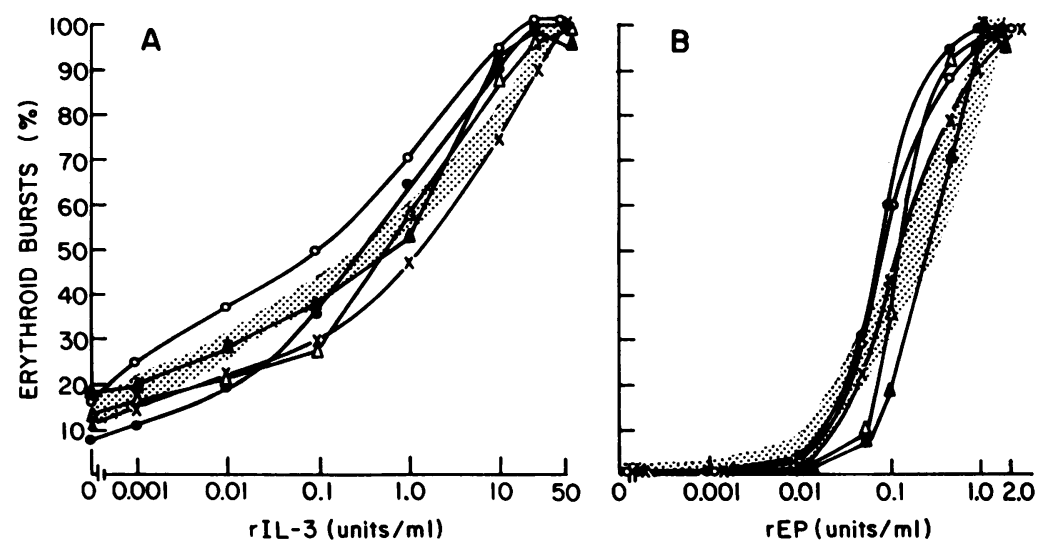

Figure 3. rIL-3 $(A)$ and EP $(B)$ dose-response curves for blood BFU-E from five secondary polycythemia patients. The BFU-E were plated at $100-150$ cells/ml with $\mathrm{rEP} 2$ $\mathrm{U} / \mathrm{ml}(A)$ or rIL-3 $50 \mathrm{U} / \mathrm{ml}(B)$. The shaded areas represent the range of response for normal BFU-E shown in Fig. 2. Each point represents the mean value from three clots and is expressed as a percentage of the value obtained with the highest concentration of rIL-3 or rEP. The purity of the secondary polycythemia BFU-E was $61 \pm 6 \%, 51 \pm 5 \%, 40 \pm 6 \%, 30 \pm 2 \%$, and $51 \pm 11 \%$. All five subjects were treated by phlebotomy alone. 


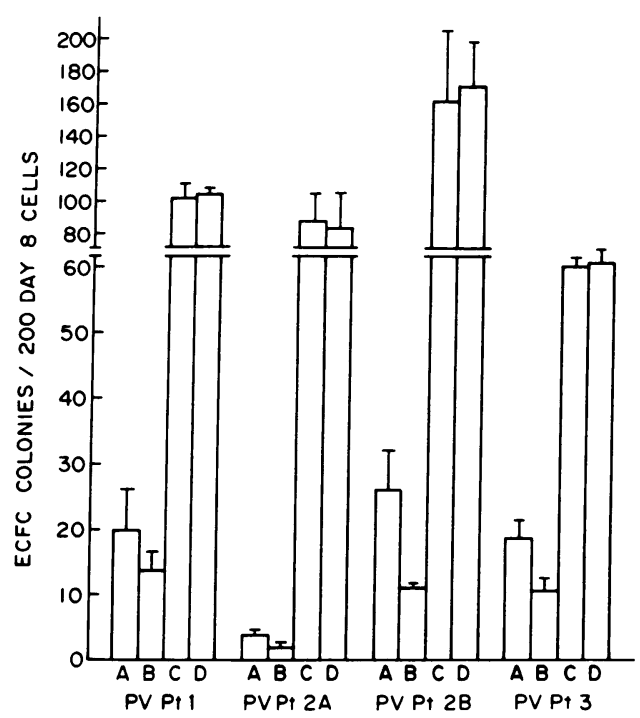

Figure 4. Role of IL-3 in EEC growth. Partially purified PV blood BFU-E were cultured in methylcellulose at $37^{\circ} \mathrm{C}$ with rIL-3 $(A, C)$ for $7 \mathrm{~d}$ (day 8 cells) to generate ECFC. These ECFC were compared to ECFC generated from BFU-E that were cultured with rIL-3 for $4 \mathrm{~d}$ and then without rIL-3 for an additional 3 days $(B, D)$. Three experiments from three separate patients with PV, plus one repeat (patient 2B) are shown. Each pool of generated ECFC was cultured at $10^{3} / \mathrm{ml}$ for $7 \mathrm{~d}$ in quadruplicate $0.2-\mathrm{ml}$ plasma clots without $\mathrm{rEP}$ $(A, B)$ or in the presence of $1 \mathrm{U} / \mathrm{ml} \mathrm{rEP}(C, D)$. EEC growth from cells exposed to rIL-3 for only $4 \mathrm{~d}$ was significantly decreased $(P$ $<0.02$ for patient $1, P<0.05$ for patient $2 \mathrm{~A}$, and $P<0.01$ for patients 2B and 3), whereas no significant effect on EP-responsive ECFC was apparent. Results are expressed as mean $\pm \mathrm{SD}$. All three patients were treated solely by phlebotomy.

ever, these experiments were performed in the past with little purification of the EP-responsive cells. In this case, the denominator, the number of BFU-E actually present amongst PV and normal hematopoietic cells, may not be accurate as the growth and differentiation of the BFU-E might be altered by the numerous contaminant accessory cells and their products. With highly purified BFU-E, this variability is greatly reduced and this may be the explanation for the variability in results from different laboratories.

Because PV BFU-E maintain a higher degree of responsiveness to rIL-3 between days 5 and 7 of growth in vitro, compared to normal BFU-E, we explored the relation of this phenomenon to the development of EEC. If rIL-3 and rEP act cooperatively in the development of these cells during the period when sensitivity to both factors is present, then the presence of one factor might create a lesser need for the other. This possibility is enhanced by the observation that PV erythroid bursts increased in size when increasing concentrations of rIL-3 were added to the BFU-E in the presence of a low concentration of rEP. Indeed, when PV BFU-E were grown without rIL-3 during days 5-8, a 50\% decrease in EEC formation was evident indicating that the increased period of sensitivity to rIL-3 is a major factor contributing to this phenomenon. In the presence of maximum concentrations of rEP, no effect of rIL-3 deprivation was evident for ECFC development. However, it is possible that the increased period of rIL-3 responsiveness may also account for the hypersensitivity of PV CFU-E to rEP when limiting amounts of rEP are present (4).
We have previously shown that PV CFU-E lack high-affinity EP receptors. Recently, Fraser et al. (31) reported that IL-3 down modulated EP receptors on murine spleen CFU-E. We have shown that rIL-3 has no effect on the growth and development of highly purified normal human CFU-E (25), but it is possible that the hypersensitivity to rIL-3 and the persistent responsiveness of PV erythroid progenitors to rIL-3, for as long as $6 \mathrm{~d}$ of maturation, might allow a down-modulation of the high-affinity EP receptors on these cells, which could persist until day 8 of incubation when the ECFC were collected and examined for EP receptors by ${ }^{125} \mathrm{I}$-Ep binding experiments. Experiments are currently underway in our laboratory to determine if incubation of PV BFU-E with rIL-3 accounts for the pattern of EP receptors that has been described.

The precise cause for the rIL-3 hypersensitivity of PV blood BFU-E is not known. One likely explanation is that these BFU$E$ are $2 \mathrm{~d}$ younger and slightly more immature. The 2-d extension of PV BFU-E sensitivity to rIL-3 may provide an additional 2-d period of reduced dependence on rEP. However, Robak (32) has performed an extensive phenotypic study of PV blood BFU-E looking at the antigenic characteristics of these cells with nine monoclonal antibodies. No qualitative differences between PV and normal blood BFU-E were found, but the percentage of normal BFU-E reacting with antibody to early and late differentiation antigens was somewhat increased compared to PV BFU-E.

Additional mechanisms are possible. PV BFU-E may have an enhanced number of IL-3 receptors or an increased binding affinity for IL-3. This can be studied by autoradiography using ${ }^{125}$ I-rIL-3. Prior autoradiographic studies with highly purified normal human BFU-E have shown a reduced number of EP receptors that increase as these cells mature to CFU-E (10). Similar studies should provide information on the relation between IL-3 sensitivity and the development of IL-3 receptors. Other possibilities for the IL-3 hypersensitivity are an enhanced sensitivity of the second messenger system, the production of another cytokine that potentiates the effect of rIL-3 (33), or the lack of production of a normal inhibitor that counteracts the activity of rIL-3 $(34,35)$. The present system provides a means for the investigation of most of these alternatives. Nevertheless, these studies indicate that the prominent abnormality in PV is an exquisite sensitivity of the blood BFUE to IL-3 which could represent the primary pathogenetic event in this condition.

\section{Acknowledgements}

The authors thank Dr. Curt I. Civin for his generous gift of murine monoclonal antibodies to CD34/anti-My10, CD15/antiMy1, CD33/anti-My9, CD45R/anti-My11, CD16/anti-My23, and CD56/anti-My31, without which this work would not have been possible, and Mrs. Pat Hofmann for her assistance in preparing this manuscript.

This work was supported by Veterans Health Services and Research Administration funds, and grants DK-15555, 2 T32 DK07186, RR-95, and RR-50 from the National Institutes of Health and The Joe C. Davis Hematology Research Fund. Dr. Means is an Associate Investigator of the VA Career Development Program.

\section{References}

1. Adamson, J. W., P. J. Fialkow, S. Murphy, J. F. Prchal and L Steinmann. 1976. Polycythemia vera: stem cell and probable clonal origin of the disease. $N$. Engl. J. Med. 295:913-916. 
2. Prchal, J. F., J. W. Adamson, S. Murphy, L. Steinmann, and P. J. Fialkow. 1978. Polycythemia vera. The in vitro response of normal and abnormal cell lines to erythropoietin. J. Clin. Invest. 61:1044-1047.

3. Prchal, J. F., and A. A. Axelrad. 1974. Bone marrow responses in polycythemia vera. N. Engl. J. Med. 290:1382.

4. Zanjani, E. D., J. D. Lutton, R. Hoffman, and L. R. Wasserman. 1977. Erythroid colony formation by polycythemia vera marrow in vitro. Dependence on erythropoietin. J. Clin. Invest. 59:841-844.

5. Golde, D. W., N. Bersch, and M. J. Cline. 1977. Polycythemia vera. Hormonal modulation of erythropoiesis in vitro. Blood. 49:399-405.

6. Casadevall, N., W. Vainchenker, C. Lacombe, G. Vinci, J. Chapman, J. Breton-Gorius, and B. Varet. 1982. Erythroid progenitors in polycythemia vera. Demonstration of their hypersensitivity to erythropoietin using serum-free cultures. Blood. 59:447-451.

7. Eaves, A. C., G. Krystal, J. D. Cashman, and C. J. Eaves. 1988. Polycythemia vera: in vitro analysis of regulatory defects. In Regulation of Erythropoiesis. E. D. Zanjani, M. Tavassoli, and J. L. Ascensao, editors. PMA Publishing Corp., New York.

8. Eridani, S., J. M. Dudley, B. M. Sawyer, and T. C. Pearson. 1987. Erythropoietic colonies in a serum-free system: results in primary proliferative polycythemia and thrombocythemia. Br. J. Haematol. 67:387-391.

9. Means, R. T., Jr., S. B. Krantz, S. T. Sawyer, and H. S. Gilbert. 1989. Erythropoietin receptors in polycythemia vera. J. Clin. Invest. 84:1340-1344.

10. Sawada, K., S. B. Krantz, C.-H. Dai, S. T. Koury, S. T. Horn, A. D. Glick, and C. I. Civin. 1990. Purification of human blood burst-forming units-erythroid and demonstration of the evolution of erythropoietin receptors. J. Cell. Physiol. 142:219-230.

11. Sieff, C. A., S. G. Emerson, A. Mufson, T. G. Gesner, and D. G. Nathan 1986. Dependence of highly enriched human bone marrow progenitors on hematopoietic growth factors and their response to recombinant erythropoietin. $J$ Clin. Invest. 77:74-81.

12. Emerson, S. G., S. Thomas, J. L. Ferrara, and J. L. Greenstein. 1989. Developmental regulation of erythropoiesis by hematopoietic growth factors analysis on populations of BFU-E from bone marrow, peripheral blood, and feta liver. Blood. 74:49-55.

13. Sieff, C. A., C. M. Niemeyer, D. G. Nathan, S. C. Ekern, F. R. Bieber, Y. C. Yang, G. Wong, and S. C. Clark. 1987. Stimulation of human hematopoietic colony formation by recombinant gibbon multi-colony-stimulating factor or interleukin 3. J. Clin. Invest. 80:818-823.

14. Berlin, N. I. 1975. Diagnosis and classification of the polycythemias. Semin. Hematol. 12:339-351.

15. McLeod, D. L., M. M. Shreeve, and A. A. Axelrad. 1974. Improved plasma culture system for production of erythrocytic colonies in vitro. Quantitative assay method for CFU-E. Blood. 44:517-534.

16. Civin, C. I., L. C. Strauss, C. Brovall, M. J. Fackler, J. F. Schwartz, and J. H. Shaper. 1984. Antigenic analysis of hematopoiesis. III. A hematopoietic progenitor cell surface antigen defined by a monoclonal antibody raised against KG-1a cells. $J$. Immunol. 133:157-165.

17. Strauss, L. C., S. D. Rowley, V. F. La Russa, S. J. Sharkis, R. K. Stuart, and C. I. Civin. 1986. Antigenic analysis of hematopoiesis. V. Characterization of My-10 antigen expression by normal lymphohematopoietic progenitor cells. Exp. Hematol. 14:878-886.

18. Civin, C. I., and M. R. Loken. 1987. Cell surface antigens on human marrow cells. dissection of hematopoietic development using monoclonal antibodies and multiparameter flow cytometry. Int. J. Cell Cloning. 5:267-288.
19. McMichael, A. J., P. C. L. Beverley, S. Cobbold, M. J. Crumpton, W. Gilks, F. M. Gotch, N. Hogg, M. Horton, N. Ling, I. C. M. MacLennan, D. Y. Mason, C. Milstein, D. Spiegelhalter, and H. Waldmann, editors. 1987. Leukocyte Typing III: White Cell Differentiation Antigens. Oxford University Press, Oxford. $1050 \mathrm{pp}$.

20. Strauss, L. C., C. Brovall, M. J. Fackler, J. F. Schwartz, J. H. Shaper, M. R. Loken, and C. I. Civin. 1986. Antigenic analysis of hematopoiesis. IV. The My-11 hematopoietic cell surface antigen is expressed by myelomonocytic and lymphoid, but not erythroid, progenitor cells. Exp. Hematol. 14:935-945.

21. Knapp, W., B. Dorken, W. R. Gilks, E. P. Rieber, R. E. Schmidt, H. Stein, and A. E. G. Kr. von dem Borne, editors. 1989. Leukocyte Typing IV: White Cell Differentiation Antigens. W. Knapp, editors. Oxford University Press, Oxford. $1156 \mathrm{pp}$.

22. Lanier, L. L., A. M. Le, C. I. Civin, M. R. Loken, and J. H. Phillips. 1986. The relationship of CD16 (Leu-11) and Leu-19 (NKH-1) antigen expression on human peripheral blood NK cells and cytotoxic T lymphocytes. J. Immunol. $136: 4480-4486$

23. Zaentz, S. D., J. A. Luna, A. S. Baker, and S. B. Krantz. 1977. Detection of cytotoxic antibody to erythroblasts. J. Lab. Clin. Med. 89:851-860.

24. Sawada, K., S. B. Krantz, J. S. Kans, E. N. Dessypris, S. Sawyer, A. D. Glick, and C. I. Civin. 1987. Purification of human erythroid colony-forming units and demonstration of specific binding of erythropoietin. J. Clin. Invest. 80:357-366.

25. Sawada, K., S. B. Krantz, E. N. Dessypris, S. T. Koury, and S. T. Sawyer. 1989. Human colony-forming units-erythroid do not require accessory cells, but do require direct interaction with insulin-like growth factor-I and/or insulin for erythroid development. J. Clin. Invest. 83:1701-1709.

26. Sawada, K., S. B. Krantz, S. T. Sawyer, and C. I. Civin. 1988. Quantitation of specific binding of erythropoietin to human erythroid colony-forming cells. $J$. Cell. Physiol. 137:337-345.

27. Clark, B. J., and D. Housman. 1977. Characterization of an erythroid precursor cell of high proliferative capacity in normal human peripheral blood. Proc. Natl. Acad. Sci. USA. 74:1105-1109.

28. Reid, C. D. L. 1987. The significance of endogenous erythroid colonies (EEC) in haematological disorders. Blood Rev. 1:133-140.

29. Eaves, C. J., and A. C. Eaves. 1978. Erythropoietin (Ep) dose response curve for three classes of erythroid progenitors in normal human marrow and in patients with polycythemia vera. Blood. 52:1196-1210.

30. Lacombe, C., N. Casadevall, and B. Varet. 1980. Polycythemia vera: in vitro studies of circulating erythroid progenitors. Br. J. Haematol. 44:189-199.

31. Frazer, J. K., J. Nicholls, C. Coffey, F.-K. Lin, and M. V. Berridge. 1988. Down-modulation of high-affinity receptors for erythropoietin on murine erythroblasts by interleukin 3. Exp. Hematol. 16:769-773.

32. Robak, T. 1988. Antigenic characteristics of erythropoietin dependent and independent erythroid progenitors (BFU-E and CFU-E) in polycythemia vera and idiopathic myelofibrosis defined by monoclonal antibodies. Arch. Immunol. Ther. Exp. 36:733-747.

33. Eid, J., R. F. Ebert, M. S. Gesell, and J. L. Spivak. 1987. Intracellular growth factors in polycythemia vera and other myeloproliferative disorders. Proc. Natl. Acad. Sci. USA. 84:532-536.

34. Cashman, J. D., C. J. Eaves, and A. C. Eaves. 1988. Unregulated proliferation of primitive neoplastic progenitor cells in long-term polycythemia vera marrow cultures. J. Clin. Invest. 81:87-91.

35. Pluthero, F. G., M. Shreeve, D. Eskinazi, and A. A. Axelrad. 1989. An antagonist to IL-3 produced by mouse cells. Blood. 74:74a. (Abstr.) 